\title{
Professional Foreign Language Training in the Context of the Digital University
}

\section{Example of Modeling and Experimental Validation}

\author{
https://doi.org/10.3991/ijep.v11i6.23421 \\ Gulnara Rizakhojayeva ${ }^{1(\varpi)}$, Guzal Yussupova ${ }^{1}$, Bagila Mamyrbayeva $^{2}$, \\ Akylbek Meirbekov ${ }^{1}$ \\ ${ }^{1}$ Khoja Akhmet Yassawi International Kazakh-Turkish University, Turkestan, Kazakhstan \\ ${ }^{2}$ Silkway International University, Shymkent, Kazakhstan \\ rizahodjaevaayu.edu.kz@bk.ru
}

\begin{abstract}
Currently, the practical level of foreign language proficiency of philology graduates does not always correspond to the social order of society. In this paper, a model for professional foreign language training of philology students was developed, theoretically justified and experimentally tested. For this purpose, the Moodle tool was widely deployed and we identified and experimentally tested pedagogical conditions that ensure the effectiveness of professional foreign language training for philology students. The experimental work involved a random sample of 305 students of the "bachelor" level of the training direction 5B021000 (6B023)-foreign philology. The result of the qualitative and quantitative analysis allows to conclude the effectiveness of the proposed model of professional foreign language training of philology students based on Moodle, which is confirmed by the calculations during the statistical processing of the research results. The scientific novelty of the study is that the pedagogical conditions that ensure the effectiveness of the Moodle-based professional foreign language training of philology students were identified and experimentally tested. The results of the study showed the effectiveness of using distance learning in the current health context due to the COVID-19 pandemic.
\end{abstract}

Keywords - digitalization, educational environment, foreign language learning, professional competence, pedagogical conditions

\section{Introduction}

In the context of the emergence of the global socio-economic crisis caused by the pandemic of COVID-19, the formation and sustainable development of the digitalization of the country's economy and, in particular, education has become particularly relevant. At the same time, two main problems can be noted: the state of communication networks that do not meet the current needs of online distance education, as well as the mismatch between the digital skills of teachers and modern technical capabilities [1,2]. 
The first of these issues concerns the choice of an optimal educational platform, a unified system of access to knowledge bases, as well as technical issues related to the creation of high-speed communication systems of the $5 \mathrm{G}$ standard, which allow the transmission of large amounts of data and are currently already implemented in a number of countries in Europe and Asia, which will allow distance learning in universities, helping to slow the spread of the pandemic in the world.

Regarding the second problem, it should be noted that a significant part of teachers in large universities have already been trained, master the modern technologies of distance learning of students and have developed the necessary methodological materials, nevertheless, there is a rapid trend in universities to create and use electronic educational resources of insufficient quality. In an attempt to maintain the level of the educational process before the crisis, universities are introducing an information and education environment, using open distance learning systems.

The above-mentioned global changes have affected the educational process in general, and in particular the professional foreign language training of philology bachelors.

Modern research reflects various aspects of the problem of implementation of foreign language training of philology students in the informational and educational environment. Despite the existence of studies $[3,4]$ on the problem of professional foreign language training of philology students in the informational and educational environment, the contradictions between professional foreign language training and professional foreign language training are not always obvious:

- The need to strengthen the motivation of philology students for professional training in foreign languages by means of information and communication technologies in connection with the global digitization of education and the lack of theoretical and practical development of the problem of effective use of the above mentioned technologies.

- The educational potential of information and communication technologies and the lack of digital skills of philology students in universities.

- The existing need for specialists speaking a foreign language at a professional level, and the insufficient number of effective e-learning courses for universities used in teaching a foreign language in the context of the global digitalization of education.

In this context, the problem of implementing professional foreign language training for future philologists in the informational and educational environment, taking into account informational and digital trends in national education, becomes particularly relevant.

To address the above problem, we propose to introduce a model of professional foreign language training of philology students in the university's computer and educational environment based on Moodle into the educational process. The latter allows to increase the efficiency of the training of professional foreign language competence of future bachelor philologists.

We also identified, justified, and used criteria (motivational, content, technological, reflective) and corresponding indicators of the initial level of training of professional foreign language competence of philology students, and also identified four levels of 
training of professional foreign language competence of prospective bachelor's degree philology students - professional, advanced, basic, and elementary.

To obtain the desired result in accordance with the objective of the study, we formulated the following research tasks:

1. Clarify the essence and structure of professional foreign language training for philology students.

2. Characterize the university's information and educational environment, identify the components of the information and educational environment in their interrelationship.

3. Determine and justify the criteria, indicators, and training levels of professional foreign language proficiency for future bachelor's degree holders in philology.

4. To theoretically justify and experimentally test pedagogical conditions that ensure effective professional foreign language training for philology students in the university's Moodle-based computing and educational environment;

5. Develop a model for professional foreign language training of philology students in the university's computer and educational environment based on Moodle and analyze the results of its implementation.

The structure of this paper is as follows. Section 2 provides a comprehensive literature review of the topic. Section 3 presents the methodological aspects of the study. Section 4 presents the main results and discusses the relevance of the proposed approach. Section 5 gives the main conclusions of this work, as well as some research perspectives.

\section{$2 \quad$ Literature review}

Modern globalization processes, covering all spheres of life, set high requirements for future specialists of higher education, in general, and for philologists, in particular. Today, the optimization of foreign-language professional training of future philologists, including in the information and educational environment, is relevant $[5,6]$. In this regard, one of the main prerequisites of this study is to consider the nature and structure of foreign language professional training of students of philology, increasing the effectiveness of which causes considerable interest of researchers to this issue.

The scope of the concept of "training" generally includes the smaller concepts of "professional training" and "professional training of students of philology", as well as" foreign language professional training "and" foreign language professional training of students of philology" [7].

Let us turn to the structure of the professional training system, which is represented by cognitive, activity and personal components, in the interaction of which high-quality training of specialists is achieved, the formation of their readiness for professional activity [8]. The cognitive component is a set of knowledge necessary for the implementation of professional activities, its content assumes the presence of relevant knowledge that students master in the process of studying the disciplines of the basic and variable blocks of the curriculum. The activity component reflects the formation of students' 
groups of skills for professional activity, the necessary competencies. The personal component reflects the desire of the individual to improve his professional status, to gain recognition from peers and teachers, and to improve his reputation.

In this study, based on the general definitions of the term "professional training" analyzed above, we will consider the professional training of students of philology as a process of mastering their competencies (knowledge, skills and abilities) that allow them to perform professional philological tasks.

The set of disciplines of the basic and variable parts of the curriculum offered in the framework of foreign-language professional training of students of philology provides the formation of their foreign-language professional competence. Let us consider successively two concepts: "foreign language professional training" and "foreign language professional competence".

Various aspects of foreign language professional training are reflected in the works of such scientists: Niemelä \& Naukkarinen [9]. In particular, professionally oriented English teaching has been considered as a scientific direction with the study of its theoretical aspects, essence and teaching methods since the middle of the 20th century.

Summarizing the research of scientists, we define the essence of foreign language professional training of future specialists in the field of philology as a complex controlled process of mastering special foreign language knowledge and skills, namely, the formation of foreign language professional competence in students.

The formation and development of professional readiness cannot be carried out to the full extent if a diagnostic device has not been developed, with the help of which it would be possible to assess the level of professional readiness. Diagnostics is aimed primarily at identifying strengths and weaknesses in the professional activity of a teacher, his potential capabilities and needs, allows you to anticipate possible difficulties in the implementation of the learning process. A large number of researchers are engaged in the development of assessment systems [10, 11].

The educational process in the information and educational environment not only affects the quality of education, but also contributes to the involvement of the teacher in promoting the development of a highly professional personality of a philologist student, which is confirmed by the increased level of attention to this topic of scientists, whose research presents certain aspects of the modern educational environment, as well as the problems of professional competence formation in the context of global digitalization of society [12-14].

In his work, V. V. Gura defines this environment as "under the set" of the educational process with its system-forming conditions, means, and opportunities [15]. Gendina (2017), proposes the definition of the information and educational environment as an element of the information field, which has an external interaction with the information space and an internal set of conditions for the activity of an individual [16].

The COVID-19 pandemic highlighted the important role of digital technologies in higher education. Serious problems have arisen regarding the quality of distance education, the learning process itself and the assessment of knowledge and skills [17, $18]$.

Tutoring through adaptive learning activities can be a powerful tool to support students in practical courses, such as computer programming [19]. 
The analysis of the above-mentioned works allowed us to define the author's concept of "environment", as applied to the individual, including the interaction of correlating factors and the person who exerts a reciprocal influence or a proactive influence on them. The individual has a reciprocal influence on the already occurred or current impact of the environmental factor. For example, the impact of the environment, such as the rapid development and availability of electronic devices, information capabilities and digital technologies, ensures the mass use of smartphones and tablets by students (retaliatory influence). At the same time, the concept of "proactive impact" can be considered as a certain behavior or response of an individual to a situation modeled in the future, which may occur due to his actions or in spite of him.

Today, it is possible to identify three key aspects in which the information environment was studied. First, as one of the aspects of activity, when a person is considered as a participant in the communication process (providing personal knowledge in the form of information); second, as a system of historically formed communication forms; third, as an information infrastructure created by the whole society, which allows for the implementation of communication activities: libraries, publishing houses, information centers, mass media, data banks, etc.

\section{$3 \quad$ Materials and methods}

\subsection{Research methodology}

The research methods include the following pillars:

Theoretical analysis of pedagogical literature on the problem of professional foreign language training of philologists; study of materials on the World Wide Web on the use of information and communication technologies in professional activities and education; analysis of computer tools used in the process of foreign language training and professional activities of philologists; analysis of the state of the problem in the existing practice, study of normative literature on the subject of research; analysis of distance learning systems and Web 2.0 services used in professional foreign language training; pedagogical modeling.

Empirical analysis of the state of the problem in the existing practice (educational programs for the training of philologists, the current organization of the educational process of philology students); diagnostic methods: questionnaires, tests, interviews; pedagogical experiment (statement, training and control) to test the effectiveness of the model of professional foreign language training of philology students in the training and teaching environment.

Statistical evaluation to process the results of the study in order to generalize the experimental data. The Student $t$ test was used with a confidence level of one percent $(p=0.01)$. To identify differences in trait distribution, we used a nonparametric Chi-2 $\left(\chi^{2}\right)$ test with an acceptable probability of error of 0.01 . Tables, charts, and graphs were used to visualize the experimental data. 


\subsection{Research stages and procedures}

The experimental work in this study was carried out at the Kazakh-Turkish International University named after Kh.A.Yassawi, Turkestan, Kazakhstan. The study was conducted from 2017 to 2020 in three phases:

- Within the framework of the theoretical and ascertaining stage (2017-2018), the current state of the problem of foreign language professional training of students of philology in the information and educational environment of the university was studied; the analysis of philosophical, psychological, pedagogical, cultural and methodological literature, normative documentation was carried out; the goals, tasks, hypotheses of the study were formulated; pedagogical conditions were justified; diagnostic tools were selected to determine the level of formation of foreign language professional competence in future bachelors of philology; The criteria, indicators, and levels of formation of foreign language professional competence among students of philology are determined; diagnostic methods are selected within the framework of a ascertaining experiment.

- The formative stage (2018-2019) was to test the effectiveness of the developed model of foreign language professional training of philology students in the information and educational environment of the university based on Moodle and provided for a formative experiment to test this model.

- At the control stage (2019-2020), the results of experimental work were analyzed and summarized, conclusions and practical recommendations were formulated to improve the process of forming foreign-language professional competence in the information and educational environment of the university for future bachelorphilologists.

The experimental work involved a random sample of 305 students from the "bachelor" level (1,2 courses) of the training direction 5B021000 (6B023)-foreign philology. The sample was randomly divided into control (150 people) and experimental (155 people) groups.

The frequency analysis of the experimental data is given in Table 1.

Table 1. Information on the student population

\begin{tabular}{|c|c|c|c|c|c|}
\hline \multicolumn{6}{|c|}{ Gender } \\
\hline \multirow{3}{*}{ Valid } & & Frequency & Percent & Valid percentage & Cumulative percentage \\
\hline & Woman & 200 & 65.6 & 65.6 & 65.6 \\
\cline { 2 - 7 } & Man & 105 & 34.4 & 34.4 & 100.0 \\
\cline { 2 - 7 } & Total & 305 & 100.0 & 100.0 & \\
\hline \multicolumn{7}{|c|}{ Training course } \\
\hline \multirow{3}{*}{ Valid } & \multicolumn{7}{|c|}{ Frequency } & Percent & Valid percentage & Cumulative percentage \\
\hline & I course & 168 & 55.0 & 55.0 & 55.0 \\
\cline { 2 - 7 } & II course & 137 & 45.0 & 45.0 & 100.0 \\
\cline { 2 - 7 } & Total & 305 & 100.0 & 100.0 & \\
\hline
\end{tabular}


Table 2 shows our proposed criteria (along with their weights, reflecting the importance of each criterion) and the corresponding indicators of the initial educational level of professional foreign language competence, along with their possible values. The possible quantitative values of the indicators are also shown, while the qualitative values are translated into quantitative measures.

Table 2. Criteria, indicators, methods for diagnosing the initial level of training of professional competence in a foreign language

\begin{tabular}{|c|c|c|c|}
\hline $\begin{array}{l}\text { The crite- } \\
\text { rion and } \\
\text { its weight }\end{array}$ & Indicators & Values & Methodology \\
\hline \multirow{2}{*}{$\begin{array}{l}\text { A. Moti- } \\
\text { vational } \\
(0,1)\end{array}$} & $\begin{array}{l}\text { A.1 Understanding the role of foreign lan- } \\
\text { guage professional competence in the fu- } \\
\text { ture professional activity of a philologist }\end{array}$ & $\begin{array}{l}\text { A. 1: "Present" (1) } \\
\text { or "Absent" (0) }\end{array}$ & $\begin{array}{l}\text { Interviewing "Foreign lan- } \\
\text { guage is a strange language in } \\
\text { my future profession»» }\end{array}$ \\
\hline & $\begin{array}{l}\text { A. } 2 \text { The presence of motivation among } \\
\text { students of philology to study a foreign } \\
\text { language in the information and educa- } \\
\text { tional environment }\end{array}$ & $\begin{array}{l}\text { A.2: "Present" (1) } \\
\text { or "Absent" (0) }\end{array}$ & $\begin{array}{c}\text { Questionnaire «How do I } \\
\text { want to learn a foreign lan- } \\
\text { guage» }\end{array}$ \\
\hline $\begin{array}{l}\text { B. Content } \\
(0,4)\end{array}$ & $\begin{array}{c}\text { B.1 Receptive and reproductive } \\
\text { knowledge of language material: B.1.1 } \\
\text { Proficiency in reading English texts B.1.2 } \\
\text { Knowledge of English grammar B.1.3 } \\
\text { Proficiency in writing in English } \\
\end{array}$ & $\begin{array}{l}\text { B.1.1: } 0 \text { to } 20 \\
\text { B.1.2: } 0 \text { to } 20 \\
\text { B.1. 3: } 0 \text { to } 20\end{array}$ & $\begin{array}{l}\text { Testing for the level of for- } \\
\text { eign language proficiency }\end{array}$ \\
\hline \multirow{2}{*}{$\begin{array}{l}\text { C. Tech- } \\
\text { nological } \\
(0,4)\end{array}$} & $\begin{array}{c}\text { C. } 1 \text { The ability to use local and cloud } \\
\text { software with a foreign language interface } \\
\text { in the learning process }\end{array}$ & $\begin{array}{l}\text { C.1 "Can do it pro- } \\
\text { fessionally" (1) or } \\
\text { "Can do it poorly" } \\
(0.5) \text { or "Can't do } \\
\text { it" (0) }\end{array}$ & $\begin{array}{l}\text { Monitoring the formation of a } \\
\text { tag cloud in an Internet ser- } \\
\text { vice Wordart.com and creat- } \\
\text { ing a video clip in Biteable }\end{array}$ \\
\hline & $\begin{array}{l}\text { C. } 2 \text { Ability to communicate digitally in a } \\
\text { foreign language in various formats }\end{array}$ & $\begin{array}{l}\text { C.2 "Can do it pro- } \\
\text { fessionally" (1) or } \\
\text { "Can do it poorly" } \\
(0.5) \text { or "Can't do } \\
\text { it" (0) }\end{array}$ & $\begin{array}{l}\text { Watching a conversation in- } \\
\text { side a mini group of students } \\
\text { in a webinar mode in } \\
\text { Mirapolis }\end{array}$ \\
\hline \multirow{2}{*}{$\begin{array}{l}\text { D. Reflex- } \\
\text { ive }(0,1)\end{array}$} & $\begin{array}{c}\text { D.1 The ability to evaluate your own } \\
\text { knowledge and skills in a foreign lan- } \\
\text { guage }\end{array}$ & $\begin{array}{l}\text { D.1 "Able" (1) or } \\
\text { "Unable" (0) }\end{array}$ & $\begin{array}{l}\text { Reflexive essay about your } \\
\text { own foreign-language profes- } \\
\text { sional training }\end{array}$ \\
\hline & $\begin{array}{c}\text { D. } 2 \text { The ability to identify ways to im- } \\
\text { prove their own skills and knowledge of a } \\
\text { foreign language }\end{array}$ & $\begin{array}{l}\text { D. } 2 \text { "Able" (1) or } \\
\text { "Unable" (0) }\end{array}$ & $\begin{array}{l}\text { Building a mental map (mind- } \\
\text { map) "The prospects of im- } \\
\text { proving my knowledge and } \\
\text { skills in a foreign language" }\end{array}$ \\
\hline
\end{tabular}

In addition, the study also identifies four levels of formation of foreign language professional competence in future bachelors of philology: professional, advanced, basic and elementary (see Table 3). At the same time, quantitative values are defined for each level as a weighted sum of the values of the criteria indicators. For example, the quantitative value of the motivational criterion (A) at the professional level is "2" as a result of summing up the values of indicators A. 1 and A. 2 that correspond to this criterion (see Table 2). Then the resulting sum is adjusted to take into account the weight of the criterion ( 0.1 , reflecting its significance in the experiment): $0.1 \times 2=0.2$. Then, if the student is at the professional level for each of the four criteria $(A, B, C, D)$, the final 
(aggregated) level of formation of foreign-language professional competence is calculated as the sum of the weighted values of individual levels.

Table 3. Niveaux de formation des compétences professionnelles en langues étrangères des futurs bacheliers-philologues selon les critères suivants.

\begin{tabular}{|c|c|c|c|}
\hline Professional & Advanced & Basic & Elementary \\
\hline \multicolumn{4}{|c|}{ A. Motivational criterion $(0,1)$} \\
\hline $\begin{array}{l}\text { Understands the role of } \\
\text { English in future profes- } \\
\text { sional activities and is } \\
\text { motivated to study it; }\end{array}$ & $\begin{array}{c}\text { The presence of a } \\
\text { vaguely formulated own } \\
\text { theory of success and } \\
\text { ways to achieve it }\end{array}$ & \begin{tabular}{|} 
Understands the role of \\
English in future profes- \\
sional activities, but is not \\
motivated to study it; there \\
is no own theory of success
\end{tabular} & $\begin{array}{l}\text { Does not understand the } \\
\text { role of English in future } \\
\text { professional activities } \\
\text { and is not motivated to } \\
\text { study it. }\end{array}$ \\
\hline \multicolumn{4}{|c|}{ B. Content criterion $(0,4)$} \\
\hline $\begin{array}{l}\text { Professionally has the } \\
\text { skills of reading English- } \\
\text { language texts, listening, } \\
\text { speaking and writing in } \\
\text { English, knows the gram- } \\
\text { mar perfectly }\end{array}$ & $\begin{array}{c}\text { At a sufficient level, he } \\
\text { has the skills of reading } \\
\text { English-language texts, } \\
\text { listening, speaking and } \\
\text { writing in English, and } \\
\text { knows grammar per- } \\
\text { fectly }\end{array}$ & $\begin{array}{l}\text { At the basic level, he has } \\
\text { the skills of reading Eng- } \\
\text { lish-language texts, listen- } \\
\text { ing, speaking and writing } \\
\text { in English, and knows the } \\
\text { basics of grammar }\end{array}$ & $\begin{array}{l}\text { Fragmentary skills in } \\
\text { reading English texts, } \\
\text { listening, speaking and } \\
\text { writing in English, does } \\
\text { not know grammar }\end{array}$ \\
\hline \multicolumn{4}{|c|}{ C. Technological criterion $(0,4)$} \\
\hline $\begin{array}{l}\text { Constantly uses infor- } \\
\text { mation and communica- } \\
\text { tion technologies when } \\
\text { learning English: profes- } \\
\text { sionally knows how to } \\
\text { navigate in English-lan- } \\
\text { guage digital content. }\end{array}$ & $\begin{array}{l}\text { Search for the necessary } \\
\text { information and partici- } \\
\text { pate in digital communi- } \\
\quad \text { cation in English }\end{array}$ & $\begin{array}{l}\text { Search for the necessary in- } \\
\text { formation, but does not } \\
\text { participate in digital com- } \\
\text { munication in English }\end{array}$ & $\begin{array}{l}\text { Does not know enough } \\
\text { about English-language } \\
\text { digital content, does not } \\
\text { know how to search for } \\
\text { the necessary infor- } \\
\text { mation and participate in } \\
\text { digital communication in } \\
\text { English }\end{array}$ \\
\hline \multicolumn{4}{|c|}{ D. Reflexive criterion $(0,1)$} \\
\hline $\begin{array}{l}\text { Able to assess and iden- } \\
\text { tify ways to improve their } \\
\text { own knowledge and skills } \\
\text { in English, analyze and } \\
\text { understand the reasons for } \\
\text { their current level }\end{array}$ & $\begin{array}{l}\text { Able to assess their own } \\
\text { knowledge and skills in } \\
\text { English, analyze and un- } \\
\text { derstand the reasons for } \\
\text { their current level }\end{array}$ & $\begin{array}{c}\text { I can only evaluate my own } \\
\text { knowledge and skills in } \\
\text { English }\end{array}$ & $\begin{array}{c}\text { Unable to assess and } \\
\text { identify ways to improve } \\
\text { their own knowledge } \\
\text { and skills in English, an- } \\
\text { alyze and understand the } \\
\text { reasons for their current } \\
\text { level }\end{array}$ \\
\hline
\end{tabular}

We will conduct an example to determine the levels of formation of foreign-language professional competence of future bachelors of philology.

During the verification of the content criterion (B), students of the experimental and control groups were tested. Within the framework of this criterion, the complex indicator of the same name B.1 "Receptive and reproductive knowledge of language material" was evaluated with the following structure and evaluation criteria:

- B.1.1 Proficiency in reading English texts

- B.1.2 Knowledge of English grammar

- B.1.3 Proficiency in writing in English 
To determine the general level of knowledge of students in a foreign language, three tasks were used.

Evaluation criteria: 1 point was awarded to respondents who showed good training (A. $2=1$ "Present"). 0 points were awarded to respondents who showed no training (A. $2=0$ "Absent").

The first task diagnoses the degree of proficiency in reading English-language texts. The students had to read a 907-word speech by Stacy Jellison about his work in the construction industry, then answer a number of questions about the main idea of what they read. The value of B1.1 is measured on a scale from 0 to 20 , while in two groups the minimum score was 3 , and the maximum score was only 10 , which indicates insufficient formation of reading skills of foreign language texts. About $70 \%$ of the students of the experimental group and $72 \%$ of the control group can be characterized by a value of B.1.1 in the range from 3 to 6 points.

The second task diagnosed the knowledge of English grammar (B.1.2). Students were asked to fill in the gaps in the sentences by inserting the correct grammatical constructions. The value of B1.2 varies on a scale from 0 to 20 , while in both groups the minimum score was 0 (complete ignorance of grammar), and the maximum score was only 6, which indicates a weak understanding of English grammar by students.

The third task involved writing a scientific article in English and diagnosed the level of proficiency in writing skills in English (B.1.3) on a scale from 0 to 20. In the experimental and control groups, students ' scores varied from 0 to 5 , while $90 \%$ of students received from 0 to 3 points.

Thus, as a result of the assessment, individuals are identified as having basic and elementary levels of professional foreign language proficiency under this criterion.

\section{$4 \quad$ Main results and discussion}

\subsection{Pedagogical conditions selected}

Taking into account scientific papers on the pedagogical conditions of professional training of specialists $[20,21]$ and the specifics of training in the areas of $5 \mathrm{~b} 021000$ (6B023)-foreign philology, the pedagogical conditions of foreign-language professional training of students-philologists necessary for overcoming the above contradictions and effective formation of foreign-language professional competence of students are highlighted:

- Motivation for involving students of philology in the design of an accessible information and educational environment of the university based on Moodle.

- Complex application of Moodle functionality in the design of e-learning courses;

- Application of interactive methods in the process of foreign language professional training of students, their implementation using modern information and communication technologies;

- Use visualization tools and interactive support to create an electronic reflective environment in Moodle. 
Let us consider each of the pedagogical conditions sequentially.

The necessary first condition is the formation of motivation for students ' involvement in the design of the information and educational environment of the university accessible to students and teachers on the basis of the Moodle distance learning system.

Completing the tasks in this program will resolve the contradiction between the rapid trend of creating and using a large number of electronic educational resources in universities and the decrease in motivation to learn a foreign language, as a result, the motivation of future philologists to constantly improve a foreign language will increase.

It should be noted that the design of this environment is based on the following principles: multicomponence, integrality, distribution, adaptability. The multicomponent information and educational environment allows you to combine the entire complex of educational and methodological software of the educational process, including training, information and reference systems, etc. Integrality is the "information component of the environment", which includes the fundamental knowledge of foreign language training of students with the possibility of "access to world resources" [22].

Let us turn to the second pedagogical condition, which is aimed at resolving the contradiction between the high educational potential of information and communication technologies and the lack of digital competencies of students of philology. As a result, the requirement to achieve a high level of formation of digital competencies of future philologists in the current conditions of global information and digital trends will be met.

The considered pedagogical condition assumes the complex application of the Moodle functionality in the design of e-learning courses, namely: the use of all elements and resources of Moodle in the structure of the e-learning course will ensure in the future, when students work in the course, the effective formation of skills and abilities of practical knowledge of a foreign language, digital competencies of students, as well as a system for assessing the formation of foreign-language professional competence of students.

Thus, the main purpose of using the functionality of the Moodle environment discussed above is to create conditions for improving the efficiency and quality of training sessions, forming a system of objective assessment of the formation of foreign-language professional competence of students [23]. In addition, the involvement of students in the development of an online course, that is, in the creation of elements and resources of the course, motivates them to learn a foreign language.

Let us turn to the consideration of the third pedagogical condition, which involves the use of interactive methods in the process of foreign-language professional training and their implementation using modern information and communication technologies. The pedagogical condition resolves the contradiction, which consists in the fact that the practical level of foreign language proficiency of graduates with a philological education does not meet the modern social order of society. The implementation of the considered pedagogical condition will allow students of philology to ensure fluency in a foreign language in their future professional activities.

The fourth pedagogical condition is the use of visualization tools and interactive support to create an electronic reflective environment in Moodle, which results in the 
development of self-esteem and the ability of students to professional growth. The pedagogical condition provides a solution to the contradiction between the high requirements for the level of formation of foreign-language professional competence and the weak ability of philology students to analyze and correct the acquired knowledge, skills and abilities. As a result of the implementation of the considered pedagogical condition, the requirement for the formation of reflexive (critical) thinking among students of philology is achieved [24].

\subsection{Professional training model in the information and educational environment}

The formative experience consisted of three stages: indicative, process-activity, and performance-evaluation. In the experimental group, the focus was on the This study reveals the structure and interrelationships of the main components, namely the construction of the process of foreign language professional training of philology students, allows for a comparison of the objective and the final outcome.

Let us move directly to the development of a model for professional foreign language training of philology students in the computer and educational environment based on Moodle (see Figure 1). In the structure of the proposed model, it is necessary to distinguish interdependent components: target, methodological, criterion-diagnostic, content and performance blocks.

The presence of the target block of the model is due to the fact that goal setting is a prerequisite for an effective educational activity, which allows the subject of the activity to model and adjust its own developmental trajectory. In general, when planning and implementing training, the idea of setting goals is considered fundamental and consists of optimizing, that is, increasing the effectiveness of the educational process.

The target element of the model in this study is the professional foreign language training of philology students in the Moodle-based computing and educational environment.

Let us now turn to the analysis of the criteria-diagnostic block, which includes a set of criteria, indicators, levels, and diagnostic techniques. The criteria include motivation, content, technology, and reflection, as well as levels of professional foreign language proficiency training-professional, advanced, basic, and elementary.

We have proposed a model of foreign language professional training of students of philology in the information and educational environment of the university based on Moodle, considered as a complex multi-level system. Modeling in the framework of the content block of the model includes the sequence of certain actions to ensure the effectiveness of the professional foreign language training of philology students in the university's Moodle-based computing and educational environment, namely the formation of professional foreign language competence. This section reflects the stages (motivational, operational, practical and reflective), objectives, pedagogical conditions for the formation of professional foreign language competence in future philology bachelors, as well as the different types of assignments that contribute to the effectiveness of the educational process. 


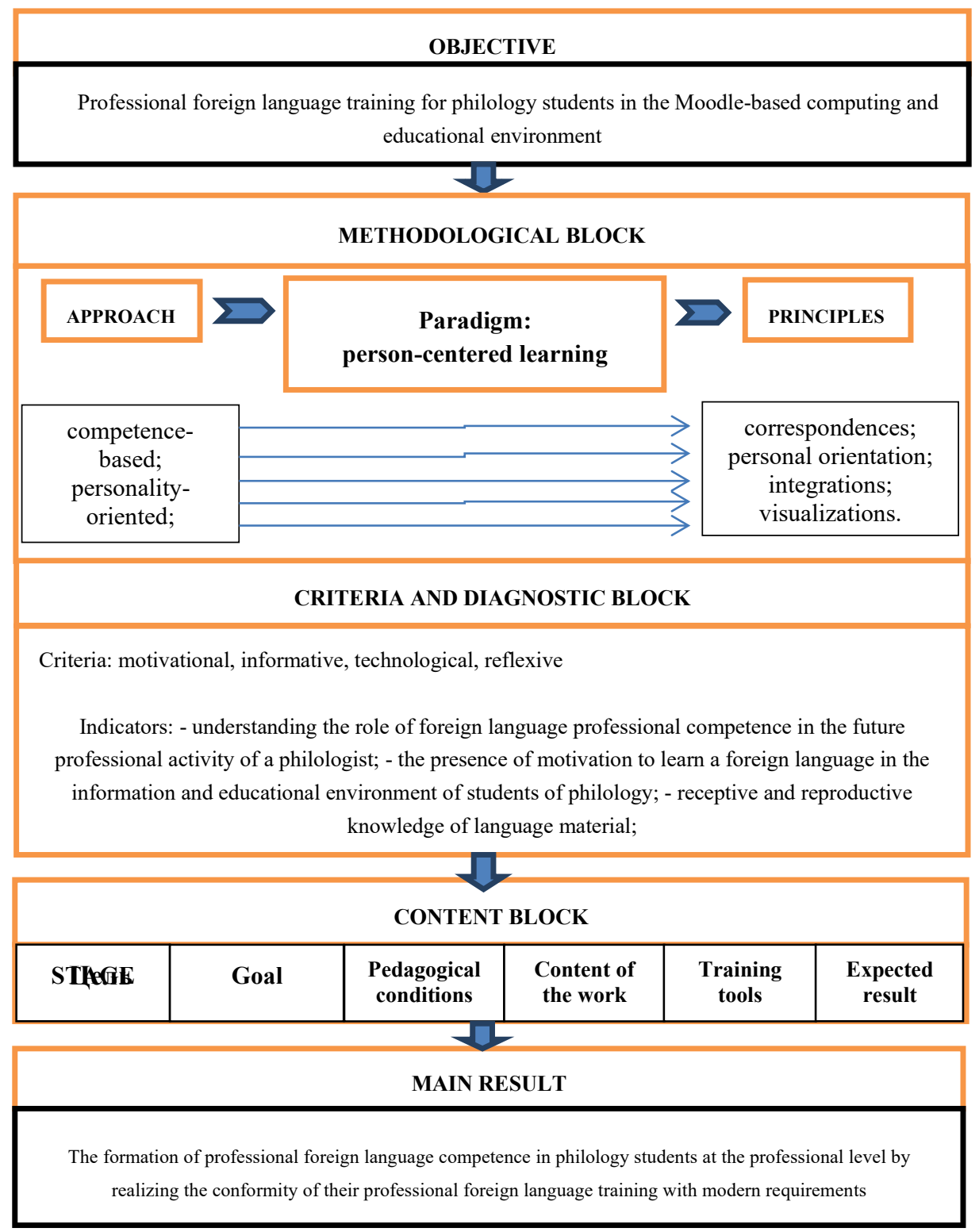

Fig. 1. Professional foreign language training model for philology students in the informational and educational environment of the university

The goal of the motivational stage is to develop the motivation of future philologists for professional foreign language training in the university's Moodle-based computing and educational environment, i.e., to form professional foreign language competence in philology students. The training tools in the first motivational stage are Moodle, Web-2 Internet services and MS Project. The expected result at this stage is a stable 
motivation of future philologists for professional foreign language training in the Moodle-based IT and educational environment.

The aim of the second stage, i.e., the operational stage, is to develop the digital skills of philology students in terms of digital foreign language skills, i.e., at this stage, operational skills are developed to work with technical training tools, including Moodle functionality and Internet services in the development and training in e-learning courses. The training tools in the operational stage are: Moodle and Web-2 Internet services, networked communication technologies (forums, chats), where the outcome is the possession of digital foreign language skills and competencies.

During the implementation of the third stage, i.e., the practical stage of the model, philology students acquire a professional level of foreign language competence in a real and virtual environment.

In the proposed model, the objective of the reflective stage is the development of the student's self-esteem and the organization of reflection in professional foreign language training using information and communication technologies.

The model proposed in this section is a complex multilevel system. Its structure reflects the interrelated components of philology students' professional foreign language training, which contributes to the development of a theoretically justified content of the work on the formation of philology students' professional foreign language competence at the professional level by realizing the conformity of their professional foreign language training to modern requirements.

\subsection{Comparative analysis of the results of the experimental work}

Digitalization is creating and will continue to create more and more opportunities in the future for the use of automated digital tools in education and solutions in the form of artificial intelligence that can be scalable and widely applied for distance learning, as evidenced by the COVID-19 crisis. It is possible to show some studies based on a comparative analysis of entrepreneurship teaching, analysis of statistical data and a survey conducted by the authors $[25,26]$.

We will conduct a comparative analysis of the results of the formation of foreign language professional competence of students of philology according to each of the identified criteria after the ascertaining and forming stages of the experiment.

In general, the effectiveness of the results of the implementation of the developed and implemented model of foreign language professional training of students of philology in the information environment of the university based on Moodle was evaluated by comparing the average indicators of the experimental and control groups obtained at the ascertaining and control stages of the study. The final results for all criteria, given their weights, are presented in Table 4 and Figure 2.

According to the results of the ascertaining experiment, we state that two random samples of students of philology, namely, the control and experimental groups, are almost identical and do not significantly differ from each other.

The primary diagnosis indicates that only $7 \%$ of students in the experimental and $5 \%$ of students in the control groups are at the professional level of formation of foreign-language professional competence. At the same time, at the advanced level, these 
indicators take the values of $10 \%$ and $13 \%$, respectively, which indicates a low loss of foreign language professional training of philology students in general. Most of the students in the two groups are at the basic level: $47 \%$ and $46 \%$, respectively.

According to the results of the control stage in the experimental group, the professional level was revealed in $20 \%$ of students against $6 \%$ of the control group respondents. According to the results of the control experiment, $42 \%$ of future bachelor's philologists of the experimental group and $13 \%$ of students of the control group were at the advanced level.

In the experimental group, $30 \%$ of respondents were identified at the basic level, in the control group $-46 \%$ of students. The elementary level was $8 \%$ of students of the experimental group, $35 \%$ of future bachelors-philologists of the control group.

Table 4. Comparative levels of formation of foreign-language professional competence.

\begin{tabular}{|l|c|c|c|c|}
\hline \multirow{2}{*}{ Level } & \multicolumn{2}{|c|}{ Control group } & \multicolumn{2}{c|}{ Experimental group } \\
\cline { 2 - 5 } & $\begin{array}{c}\text { According to the re- } \\
\text { sults of the ascertain- } \\
\text { ing experiment }\end{array}$ & $\begin{array}{c}\text { Based on the results } \\
\text { of the control exper- } \\
\text { iment }\end{array}$ & $\begin{array}{c}\text { According to the re- } \\
\text { sults of the ascer- } \\
\text { taining experiment }\end{array}$ & $\begin{array}{c}\text { Based on the results of } \\
\text { the control experiment }\end{array}$ \\
\hline Professional & $5 \%$ & $6 \%$ & $7 \%$ & $20 \%$ \\
\hline Advanced & $13 \%$ & $13 \%$ & $10 \%$ & $42 \%$ \\
\hline Basic & $46 \%$ & $46 \%$ & $47 \%$ & $30 \%$ \\
\hline Elementary & $36 \%$ & $35 \%$ & $36 \%$ & $8 \%$ \\
\hline
\end{tabular}

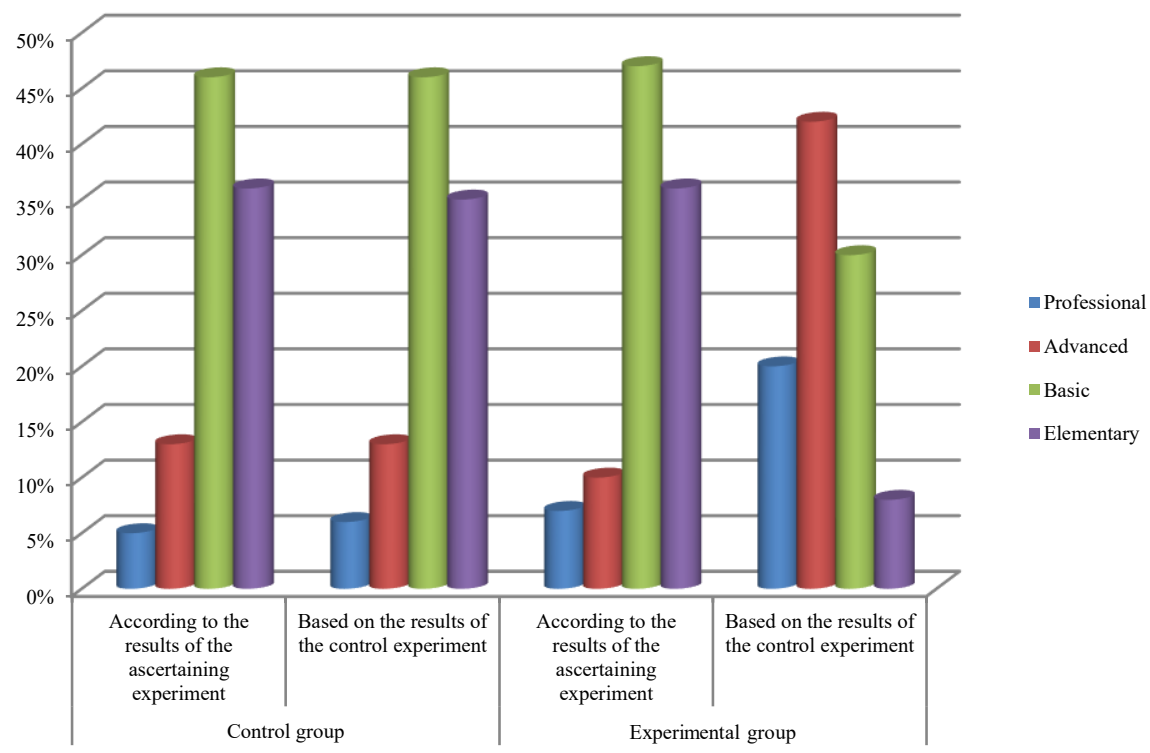

Fig. 2. Comparative levels of training in professional foreign language competence 
The results of the quantitative analysis conducted allow us to state that there is a significant, statistically significant difference in the level of training of professional foreign language competence of the students in the experimental group and the control group after the implementation of the proposed model of professional foreign language training of philology students in the university's Moodle-based computing and educational environment.

In this regard, it is necessary to test the statistical hypothesis $\left(H_{0}\right)$ about the equality of the averages of the two general populations.

To process the experimental data, we apply the "chi-square criterion" $\chi^{2}$. This random variable is used to compare the distribution of objects of two aggregates by the state of some property on the basis of measurements on the scale of names of this property in two independent samples of these aggregates. The calculation of the statistical values was done according to (1).

$$
T=\frac{1}{n} \sum_{i=1}^{c} \frac{\left(n_{1} O_{2 i}-n_{2} O_{1 i}\right)^{2}}{O_{1 i}+O_{2 i}}
$$

For $c=4(i=\{1,2,3,4\})$ we get:

$$
T=\frac{1}{n_{1} n_{2}} \sum_{i=1}^{4} \frac{\left(n_{1} O_{21}-n_{2} O_{11}\right)^{2}}{O_{11}+O_{21}}+\frac{\left(n_{1} O_{22}-n_{2} O_{12}\right)^{2}}{O_{12}+O_{22}}+\frac{\left(n_{1} O_{23}-n_{2} O_{13}\right)^{2}}{O_{13}+O_{23}}+\frac{\left(n_{1} O_{24}-n_{2} O_{14}\right)^{2}}{O_{14}+O_{24}}
$$

Where $T$ is the statistics of the criterion, $O$ is the observed frequencies $\left(O_{1 i}\right.$-is the number of trainees in the group that correspond to category $\mathrm{i} ; \mathrm{O}_{2 i}$ is the number of trainees in the other group that correspond to category $i ; n_{1}$ is the number of trainees in group $1 ; n_{2}$ is the number of trainees in group $2 ; \mathrm{i}$ is the category that corresponds to the level of competence formation ( $\mathrm{i}=1,2,3,4), 1$ is Elementary 2 is Basic; 3 is Advanced, 4 is Professional.

The calculation of the values of the statistics is carried out according to the formula, in which the integer values $O_{1 i}$ and $O_{2 i}$ are entered. Thus, the value of the statistics $\chi^{2}$ was found (for calculations, the software product GRETL was used (see Figure 3).

According to the obtained statistical indicators, the critical value of statistics having a distribution of $\chi^{2}$ with an error probability of $\alpha \leq 0,05$ is $T_{c r}=-2.95$.

Comparing the calculated and critical values of the criterion $\mathrm{T}$ and Tcr., we note that $T<T_{c r}$, and therefore we accept the hypothesis $H_{1}$ about different average values of the two general aggregates.

This confirms that at the end of the formative stage of the pedagogical experiment, the control and experimental groups of students are at different levels according to the level of formation of their foreign-language professional competence.

Since $p$-value $=0.01279$ is significantly less than the alpha significance level of $5 \%$, we accept an alternative hypothesis about different values of averages in two general populations (students who study in Moodle and traditionally).

The difference between the mean of the experimental group and the mean of the control group is statistically significant, so it can be concluded that the level of training in professional foreign language competence of the students in the experimental group increases. 
Considering the above, we can conclude the effectiveness of the proposed model of foreign language professional training of philology students in the university's Moodlebased IT and educational environment. In particular, the implementation of the Moodle e-learning course in the educational process is effective from the point of view of the effectiveness of teaching a foreign language to philology students, i.e., the formation of their professional foreign language competence.

\subsection{Discussion}

Analyzing the results of the verification experiment, we find that most of the respondents in the experimental and control groups ( $47 \%$ and $46 \%$, respectively) can be described as students with a basic level of professional foreign language competence. In turn, the smallest and insignificant proportion of students (5\% in the control group and $7 \%$ in the experimental group) are at the professional level. At the same time, the results of the experiment differ slightly for the identical experimental and control groups. Thus, the development and implementation of a model of professional foreign language training for future philology bachelors involving the use of online courses in Moodle is relevant to previous research [27, 28].

Some studies have shown that the control experiment was conducted to test the effectiveness of the students' professional foreign language training model, without including the university's information and educational environment for the instructional activity [29].

In our study, according to the results of the control stage in the experimental group, the professional level was revealed in $20 \%$ of the students against $6 \%$ of the respondents in the control group. $42 \%$ of the future bachelor-philologists in the experimental group and $13 \%$ of the students in the control group were at an advanced level according to the results of the control experiment. This demonstrates the effectiveness of our training model.

From the study of psychological and pedagogical literature, we can see the absence of special studies devoted to the problem of professional foreign language training of philology students in the informational and educational environment. Peeters (2018) defines the informational-educational environment as an environment for modeling foreign language interactions and, in addition, as a center of authentic foreign language methodological and educational materials with different indicators of complexity, which provides for the availability of various foreign language information resources, as well as an environment for designing and improving the educational process [30].

In addition, the content of these terms can change. From our point of view, this structure is not optimal and is quite capacitive. Therefore, summarizing the above, we come to the conclusion that the information and educational environment is an open educational system that combines educational content, software and technical tools, as well as organizational, mathematical and methodological support, information and human resources to optimize the educational process. Based on the analyzed interpretations, the previously proposed definitions and the structure of the environment as a whole, we will expand and clarify the concept of "information and educational environment". 
Paper-Professional Foreign Language Training in the Context of the Digital University: Example of ...

From our point of view, it is an open system of interactive cycles of mutual influences of the student and correlative technical, informational, psychodidactic and social factors, aimed at ensuring an effective educational process in the context of the global digitalization of the economy.

\section{Conclusions}

From the conducted research, the current scientific and practical problem of effective professional foreign language training of future specialists in the field of philology in the computer and educational environment of the university based on Moodle in the context of digitization of the educational process on the national level is solved.

The results of the research established the pedagogical conditions that guarantee the effectiveness of professional foreign language training for philology students:

- the formation of professional competence in foreign languages of philology students;

- the complex application of Moodle functionality in the design of electronic training courses;

- the use of interactive methods in the process of professional training in foreign languages and their implementation with the help of modern information and communication technologies;

- use visualization tools and interactive support to create an electronic environment for reflection in Moodle.

The model of professional foreign language training of philology students in the computer and educational environment of the university based on Moodle is developed, theoretically justified and experimentally tested, its main components in their relationship are analyzed: target, methodological, criterion-diagnostic, con-tent and effective blocks.

This model is a complex multilevel system, the structure of which reflects the interrelated components of the professional foreign language training of philology students, allowing for the development of theoretically justified work content on the formation of their professional foreign language competence at the professional level.

The result is a conclusion on the effectiveness of the proposed model of professional foreign language training of philology students in the university's Moodle-based computing and educational environment. The results are important for the theory and methodology of professional training.

The results of the study can be implemented in higher educational institutions in order to increase the level of professional foreign language competence of philology students during distance learning.

The theoretical and practical conclusions of the study are applicable to supplement the work programs of the discipline "Practical course of the main language" of the curriculum of the training direction "Philology".

Thus, in the future, philology teachers and students could also develop a learning model based on digital educational resources, which would represent joint learning to achieve the learning objectives. 


\section{Acknowledgement}

We thank the leaders of the universities in the southern region for their support of the work on these topics.

This research is funded by the Scientific Committee of the Ministry of Education and Science of the Republic of Kazakhstan (Grant No. AP08052329).

\section{$7 \quad$ References}

[1] Alhih, M., Ossiannilsson, E., and Berigel, M. (2017). Levels of interaction provided by online distance education models. Eurasia Journal of Mathematics, Science and Technology Education, 13(6), 2733-2748. https://doi.org/10.12973/eurasia.2017.01250a

[2] Kara, M., Erdoğdu, F., Kokoç, M., and Cagiltay, K. (2019). Challenges Faced by Adult Learners in Online Distance Education: A Literature Review. Open Praxis, 11(1), 5. https://doi.org/10.5944/openpraxis.11.1.929

[3] Merkulova, L., Martynova, O., and Ivkina, M. (2021). Foreign language learning at a technical university in the modern period. International Journal of Engineering Pedagogy, 10(6), 139-146. https://doi.org/10.3991/ijep.v10i6.13375

[4] Ramankulov, S., Dosymov, Y., Turmambekov, T., Azizkhanov, D., Kurbanbekov, S., \& Bekbayev, S. (2020). Integration of case study and digital technologies in physics teaching through the medium of a foreign language. International Journal of Emerging Technologies in Learning, 15(4), 142-157. https://doi.org/10.3991/ijet.v15i04.11699

[5] Kopotun, I. M., Durdynets, M. Y., Teremtsova, N. V., Markina, L. L., and Prisnyakova, L. M. (2020). The use of smart technologies in the professional training of students of the law departments for the development of their critical thinking. International Journal of Learning, Teaching and Educational Research, 19(3), 174-187. https://doi.org/10.26803/ ijlter.19.3.10

[6] Burlakova, I. I., Gribkova, O. V., Kononenko, M. M., Skudnyakova, E. V., and Sadekova, S. R. (2021). Quality management system of professional training of students on the digital technology basis. SHS Web of Conferences, 97, 01039. https://doi.org/10.1051/shsconf/ $\underline{20219701039}$

[7] Baimanova, U., Akhmedov, B., Niyazov, A., Kiyassova, K., and Kazakov, A. (2020). Training future english teachers for the formation of critical thinking in students. Asian ESP Journal, 16(52), 116-130.

[8] Akimova, O., Dorozhkin, E., Chapaev, N., Kiseleva, A., and Stroganova, A. (2021). Determination of the elements of architecture students' readiness to conduct professional activities. International Journal of Engineering Pedagogy, 11(2), 102-117. https://doi.org/10. 3991/ijep.v11i2.18431

[9] Niemelä, H., and Naukkarinen, J. (2021). On the rocky road to academia: Stumbling blocks for finnish engineering students with english as a second language. International Journal of Engineering Pedagogy, 10(6), 36-56. https://doi.org/10.3991/ijep.v10i6.14559

[10] Dudka, U. (2019). Experimental verification of the effectiveness of the structural-organizational model of training future economists by means of ICT. Problems of Engineer-Pedagogical Education, 62, 77-85. https://doi.org/10.32820/2074-8922-2019-62-77-85

[11] Vornovskaia, A. A. (2021). The results of experimental verification of the effectiveness of learner autonomy development model while teaching ba linguist students of i. kant baltic federal university. Modern High Technologies, 124-128. https://doi.org/10.17513/snt.38505 
Paper-Professional Foreign Language Training in the Context of the Digital University: Example of ...

[12] Glyanenko, K. (2016). Professional Training of Language Teachers in the Context of British Experience. Comparative Professional Pedagogy, 6(3), 74-78. https://doi.org/10.1515/rpp2016-0037

[13] Kononenko, I. (2020). Formation of professional competence of future specialists in philology during the end-to-end practice. Professional Education: Methodology, Theory and Technologies, (11), 82-95. https://doi.org/10.31470/2415-3729-2020-11-82-95

[14] Holik, I., and Sanda, I. D. (2020). The possibilities of improving communication skills in the training of engineering students. International Journal of Engineering Pedagogy, 10(5), 20-33. https://doi.org/10.3991/ijep.v10i5.13727

[15] Gura, V. V. Theoretical foundations of pedagogical design of personality-oriented electronic educational resources and environments / V. V. Gura. Rostov-on-Don: SFU Publishing House, 2007. - 320 p.

[16] Gendina, N. (2017). Information Culture and Information Literacy as a Scientific Direction and a Field of Educational Activities in Russia. In Pathways into Information Literacy and Communities of Practice: Teaching Approaches and Case Studies (pp. 167-202). Elsevier Inc. https://doi.org/10.1016/B978-0-08-100673-3.00007-1

[17] Jacques, S., Ouahabi, A., and Lequeu, T. (2020). Remote Knowledge Acquisition and Assessment During the COVID-19 Pandemic. International Journal of Engineering Pedagogy (iJEP), 10(6), 120-138. https://doi.org/10.3991/ijep.v10i6.16205

[18] Jacques, S., Ouahabi, A., and Lequeu, T. (2021). Synchronous E-learning in higher education during the COVID-19 pandemic. In IEEE Global Engineering Education Conference, EDUCON (Vol. 2021-April, pp. 1102-1109). IEEE Computer Society. https://doi.org/10. 1109/educon46332.2021.9453887

[19] Troussas, C., Krouska, A., and Sgouropoulou, C. (2021). A Novel Teaching Strategy through Adaptive Learning Activities for Computer Programming. IEEE Transactions on Education, 64(2), 103-109. https://doi.org/10.1109/te.2020.3012744

[20] Zozuliak-Sluchyk Roksoliana (2021). Application of innovative technologies as a pedagogical condition for professional training specialists of the social sphere. Collection of Research Papers Pedagogical Sciences, (92), 44-48. https://doi.org/10.32999/ksu2413$1865 / 2020-92-7$

[21] Byhar, H. P., Zvozdetska, V. H., Prokop, I. S., Pits, I. I., and Hordiichuk, O. Y. (2020). Pedagogical conditions for the development of self-educational competence of future specialists in the study of professional subjects. International Journal of Higher Education, 9(7), 257-266. https://doi.org/10.5430/ijhe.v9n7p257

[22] Caliga, M. (2018). Education: 7. Integrality of Musical Education Lesson - Praxeological Perspectives. Review of Artistic Education, 16(1), 258-264. https://doi.org/10.2478/rae2018-0029

[23] Berardi, S. (2021). Creating an online Russian as a foreign language course during the covid19 epidemic. Russian Language Studies, 19(1), 7-20. https://doi.org/10.22363/2618-81632021-19-1-7-20

[24] Alidjanov, I. A. (2020). Innovative technologies and formation of critical thinking of students. ACADEMICIA: An International Multidisciplinary Research Journal, 10(5), 441. https://doi.org/10.5958/2249-7137.2020.00231.1

[25] Mavlutova, I., Lesinskis, K., Liogys, M., and Hermanis, J. (2020). Innovative teaching techniques for entrepreneurship education in the era of digitalisation. WSEAS Transactions on Environment and Development, 16, 725-733. https://doi.org/10.37394/232015.2020.16.75

[26] Liu, P.-W. (2020). Comparative Analysis of Traditional Teaching Mode and Participatory Teaching Mode in English Major Teaching. DEStech Transactions on Social Science, Education and Human Science, (icesd). https://doi.org/10.12783/dtssehs/icesd2020/34173 
Paper-Professional Foreign Language Training in the Context of the Digital University: Example of ...

[27] Jana, P., Nurchasanah, and Adna, S. F. (2021). E-learning during pandemic covid-19 era drill versus conventional models. International Journal of Engineering Pedagogy, 11(3), 54-70. https://doi.org/10.3991/ijep.v11i3.16505

[28] Korkmaz, Ö., and Korkmaz, M. K. (2016). A Validity and Reliability Study of the Basic Electronics Skills Self-Efficacy Scale (BESS). International Journal of Engineering Pedagogy (IJEP), 6(4), 30. https://doi.org/10.3991/ijep.v6i4.6168

[29] Tama, B. J. (2017). Perbedaan Hasil Belajar Matematika Melalui Metode Team Assisted Individualization dan Metode Drill. SAP (Susunan Artikel Pendidikan), 1(3). https://doi.org/ $\underline{10.30998 / \text { sap.v1i3.1303 }}$

[30] Peeters, W. (2018). Applying the networking power of Web 2.0 to the foreign language classroom: a taxonomy of the online peer interaction process. Computer Assisted Language Learning, 31(8), 905-931. https://doi.org/10.1080/09588221.2018.1465982

\section{Authors}

Gulnara Rizakhojayeva (Ph.D.) is an Associate Professor at the Khoja Akhmet Yassawi International Kazakh-Turkish University, Turkestan, Kazakhstan. She is a member of the editorial board of several highly ranked journals. She is the author of several funded projects in the field of education. She speaks English at a high level and introduces advanced language proficiency technologies for students into the educational process (email: gulnara.rizahodjaeva@ayu.edu.kz).

Guzal Yussupova is a Ph.D. student at Khoja Akhmet Yassawi Kazakh-Turkish International University, Turkestan, Kazakhstan. She works in the Faculty of Philology, Department of English Language (email: guzal.yussupova@inbox.ru).

Bagila Mamyrbayeva is a candidate in pedagogical sciences, Associate Professor at Silkway International University, Shymkent, Kazakhstan. She is the head of the Department of Foreign Philology of the Faculty of Philology (email: mamyrbaeva_83@ mail.ru).

Akylbek Meirbekov (Ph.D.) is a member of the editorial board of several highly regarded journals. He is an associate professor at Khoja Akhmet Yassawi Kazakh-Turkish International University in Turkestan, Kazakhstan. He is the author of several funded projects in the field of education (email: akylbek@mail.ru).

Article submitted 2021-04-20. Resubmitted 2021-09-26. Final acceptance 2021-10-05. Final version published as submitted by the authors. 